\title{
A DEA MCDM Approach Applied to ESS8 Dataset for Measuring Immigration and Refugees Citizens' Openness
}

\author{
Juan Carlos Martín ${ }^{1} \cdot$ Alessandro Indelicato $^{1}$ (D)
}

Accepted: 20 November 2021 /Published online: 2 December 2021

(C) The Author(s) 2021

\begin{abstract}
The current refugees' crisis is undermining the main government coalitions of many countries in the European Union (EU), and tolerant attitudes and open admission policies toward immigrants seem to be part of the recent past history. The dilemma is gaining a lot of media attention as the public and political debate on migration is now playing an important role in all the European elections. Thus, the aim of this paper twofold. First, an analytical tool is developed to measure two synthetic indicators: (1) the citizens' openness towards immigration for 23 countries-18 EU Countries, plus Iceland, Israel, Norway, Switzerland, and Russia-included in the 2016 European Social Survey; and (2) the citizens' openness towards immigrants and refugees for 22 countries (same set without Hungary). And second, the effects of political orientation of citizens over the last synthetic indicator (immigrants and refugees) are studied. The approach of Data Envelopment Analysis (DEA) will be adopted here, with the purpose of identifying which countries are more, or less, open to the phenomenon of immigration and refugees. The results show that the Nordic countries and leftist are those which show more openness to immigration and refugees.
\end{abstract}

Keywords Immigration · Political parties · European Social Survey · Data Envelopment Analysis · Europe

Alessandro Indelicato

alessandro.indelicato101@alu.ulpgc.es

Juan Carlos Martín

jcarlos.martin@ulpgc.es

1 Institute of Tourism and Sustainable Economic Development, Universidad de Las Palmas de Gran Canaria, 35.017 Las Palmas de Gran Canaria, Spain 


\section{Introduction}

Between 1850 and 1915, over 30 million of people moved from Europe to the USA. Until 1890, most of the immigrants came from British islands, Germany, and Scandinavia and since 1880 migration phenomenon from southern and eastern Europe steadily increased because the costs of migration fell down as the transport technology improved (Keeling, 1999).

Yildiz (2016) affirms that migration and refugees' crisis are becoming quite controversial in the EU by four main events that have affected the EU immigration policy, such as the 2004-2007 Eastern enlargement, the terrorist attacks 9/11, Madrid, London, Paris, the debate about the Welfare States and the refugee crisis (Arab spring and Syria civil war).

With the increase of immigration to Europe, the political scene is changing too. Indeed, in the recent political elections, much of nationalist and anti-immigrant parties are showing up in European and National Parliaments. Some examples are Orban in Hungary where his government built a wall in his southern border, Marine Le Pen, with her nationalist ideas, is now the most voted party in France and Matteo Salvini, in Italy, where his antiimmigrant policy is closing Italian frontiers to hopeless.

Aside to judge if the Orban-Le Pen-Salvini policies are bad or good for their countries, it would be more interesting to detect whether the citizens of the more open countries regarding migration have themselves different values about immigration and immigrants. Immigrants have historically been received without animadversion by the hosts residents but the perspective is changing with the recent trends of inflows in the EU affecting national parliaments and citizens alike.

Immigration has become an important topic in the recent political agenda of the EU (Grande et al., 2019). In 2015 Europe was seeing its greatest refugee flow since World War II in which more than 200,000 refugees and migrants risked their lives in overcrowded and unsafe boats crossing the Mediterranean Sea (UNHCR, 2015). The recent refugee influx is weakening several European Union (EU) nations' key governing coalitions, but liberal views and open admittance policies to immigrants appeared to be a part of modern history (European Parliament, 2017; Geddes \& Scholten, 2016). Nevertheless, the welcoming and unwelcoming dilemma was receiving a lot of media attention (Berry et al., 2015). Thus, Greco and Polli (2020) contend that, at this point, migration has become crucial and relevant not only on the European political agendas, but also in a more general public debate.

For this reason, the aim of this paper is to analyse the immigration openness of 23 European countries, 17 EU Countries plus Iceland, Israel, Norway, Switzerland, Russia, and the UK. Specifically, this research provides an approach to construct a synthetic indicator that measures the immigration openness of the citizens of the countries under analysis. In addition, the study is extended to analyse the openness towards immigrants and refugees for 22 countries as Hungary could not be included in the dataset according to the political orientation. Using this political perspective, the paper fills an important gap in the literature as to date 
there are no studies analysing this relationship, and we contend that the result could affect the way that new extreme oriented parties can get more support for the next election polls in the EU.

Using a taxonomy of political orientation based on four categories, extreme-left, centre-left, centre-right, and extreme-right, we examine whether the immigrationrefugees openness is affected by the political orientation. Thus, it can be seen if some anti-immigration attitudes can be connected with the support for extreme-right political parties that are associated with the re-appearance of nationalist ideologies that can also contribute to anti-Muslims and general animadversion towards immigrants (Braun, 2011; Rydgren, 2008; Taras, 2012).

The present paper is divided as follows. In Section 2, some context of previous studies concerning the migration phenomenon will be presented. Section 3 describes the data and the sources used in the study. Section 4 presents the methodology used in the study, Data Envelopment Analysis (DEA) that will be applied to the data according to two different scenarios: immigration (6 indicators) and immigration-refugees (9 indicators). In Section 5, the results will be presented analysing the obtained indicators for the countries and the countries-political orientation; the relationship between the citizens' openness index towards immigrants and refugees (COITIR-9 indicators) and other interesting variables such as democracy index, civil liberties, freedom index, far-right parties' representativeness, net migration, and foreign-born residents, will also be presented. Section 6 will end the paper with the main conclusions by providing some reflections on the results emerging from the analysis and suggesting indications on future research directions.

\section{Theorical Background}

Ravenstein (1889) stated "Of course I am perfectly aware that our laws of population, and economic laws generally, have not the rigidity of physical laws, as they are continually being interfered with by human agency" (p.241). Despite this, he was one of the first researchers to study immigration from a scientific and statistical approach. He was the inventor of the nowadays called the "Laws of Immigration". Through these 12 "laws", Ravenstein (1885), affirms that people prefer to move to nearby places and in large industrial and commercial centers. In addition, he defines the profile of the person who emigrates as a country person, man, and adult. Another crucial law by Ravenstein (1885) states that large centers grow more because of immigration than the birth rate among the natives. About that, in the 19th and 20th centuries, a great wave of immigration from the European continent invaded North America. For this reason, the USA knew the first restricted visions on immigration issues, which were later portrayed, after World War II, due to the low percentage of births (Espenshade, 1995; Simon, 1985; Zolberg, 2006).

However, now Ravenstein's laws cannot be sufficient to explain the current migratory flow. According to the European Commission's Report on Statistics on Migration to Europe (2020), in 2019, almost 270 thousand people fled the war in their countries and emigrated to Europe to request political asylum, while 125 thousand people crossed borders illegally, and among them, almost 87 thousand people 
arrived in the European coasts. This phenomenon of new forms of immigration is also due to the Afghan crisis that began at the beginning of the 21 st century and the Arab Springs that began in Tunisia in 2011 and that spread to Egypt, Yemen, Bahrain, Morocco, Yemen, Libya, and Syria (Balcilar \& Nugent, 2019). Thus, the migration crisis began to be characterized by large flows of asylum seekers and illegals from Syria, Afghanistan, Iran, and other war-torn African countries (Heath \& Richards, 2019).

According to Slominski and Trauner (2018), the new refugee migration crises caused that asylum applications will be multiplicated, but especially in four countries within the European Union: Germany, Hungary, Sweden, and Austria. Germany decided to temporarily suspend the conditions of the Dublin treaty for Syrians, but divergent interests within the EU have been particularly visible in its application, which provides reception responsibilities to the countries of the arrival of immigrants (Slominski \& Trauner, 2018).

To avoid divergences, the German government, together with others northern EU countries, has pushed the use of financial and administrative resources provided by the EU to address the institutional deficit of the migration and asylum systems of Italy and Greece. This, however, was insufficient and the EU demonstrated not having sufficient instruments and competencies in social policy and immigration integration policies (Thym \& Hailbronner, 2016).

A number of difficulties appeared in the EU to guarantee a common policy of immigration and refugees. For example, Germany, in 2015, began to adopt "asylum packages" to reduce social benefits for asylum seekers (Slominski \& Trauner, 2018). It became evident that not all countries want to raise the costs of the Dublin treaty. Similarly, Hungary denied entry of asylum seekers from Austria under the Dublin rules (Zalan, 2016). According to the Austrian government, Hungary had to accept their applications, while the Orban government took advantage of the poor clarity of the Dublin treaty, and argued that asylum seekers in Austria should be returned directly to Greece or Bulgaria, where they first entered to the EU (Thym \& Hailbronner, 2016).

Beyond what are the causes of immigration and refugees as well as how the phenomenon is handled by different countries, it is evident that immigrants and refugees have an effect in citizens' attitudes. The literature on attitudes towards immigrants focuses on some psychological and social factors as well as some structural social settings. Interesting psychological and social factors provide a more complete view of why and how people have certain attitudes about immigration, but only a few researchers incorporate them in the analysis (Berg, 2015). This is mainly due to the difficulty of finding adequate datasets that deal with attitudes towards immigration and refugees (Shapira, 2013).

In the literature, some studies have analysed the identity of people to detect the origin of negative attitudes towards specific groups. For example, authoritarian people, who distrust other groups, increase rigor and discipline-oriented authority (Allport et al., 1954). Therefore, a negative attitude is transmitted from an individual and is directed outward to specific groups. Several studies analyse the differences between internal and external groups to explain attitudes towards immigration. In their models, they use people's status as predictors, such as racial identity, ethnicity, 
and belonging to certain political currents. Studies have highlighted how Latinos and Republicans in the USA tend to be pro and anti-immigrant, respectively, due to sociocultural and group-oriented political values (e.g., Barreto et al., 2009; Berg, 2010; Hawley, 2011; Rocha et al., 2011; Sanchez, 2006).

Thus, political values can play a determinant role in forming attitudes towards immigrants and refugees. According to Cohrs and Stelzl (2010), in Europe, but especially in Germany and Italy, people with anti-immigrant attitudes tend to be people with a right-wing authoritarian disposition. Moving from the individual level to the aggregate level, Semyonov et al. $(2006 \mathrm{a}, \mathrm{b})$ point out that the European countries that present more supporters of right-wing extremist parties also present greater anti-foreign attitudes.

The symbiosis that exists between political values, attitudes towards immigrants and refugees and political parties' discourses caused that the phenomenon of immigration penetrated the political debate in the EU favouring the explosion of nationalist parties in National Parliaments. In fact, Green-Pedersen and Mortensen (2015a, b) showed how conservative and nationalist parties tend to have more radical and negative attitudes towards immigrants than other parties. For this reason, in a circumstance of the migration crisis, where some native low-skill workers see immigrants as a threat to their economic stability, the firm positions that these parties assume against immigration have pushed a large part of the population Europe began to shelter its fears in the anti-immigrant ideologies of far-right parties (Ivarsflaten, 2005a, b; Van der Brug et al., 2000; Van der Brug \& Fennema, 2003; Van Spanje, 2010).

\section{Data}

Table 1 shows some basic information of the countries included in the analysis: (1) Democracy Index; (2) Civil liberties; (3) Freedom in the world; (4) Right party; (5) Net migration; and (6) Foreign-born residents. The information has been obtained from different data sources. Our intent is to compare how the citizens' openness index towards immigration and refugees (COITIR) is related to these variables which can be interrelated, and whether this relationship is strong or not. Important insights are derived from the analysis.

Democracy index is obtained from data available online at the Economist Intelligence Unit (EUI, 2019). The index is based on sixty indicators and their respective five categories: (1) Electoral process and pluralism; (2) Civil liberties; (3) Functioning of government; (4) Political participation; (5) Political culture. Civil liberties index is obtained from one of the categories included in the Democracy Index. Civil liberties index resembles the protection of human rights that includes freedom of speech, freedom of expression, a free press, freedom of religion, the rights to assembly and association, and the right to a fair judicial process.

Freedom in the world index contains information provided by Freedom House staff members and consultants. The index is based on political rights and civil liberties derived from the Universal Declaration of Human Rights. 
Table 1 List of countries. Raw basic information

\begin{tabular}{|c|c|c|c|c|c|c|c|}
\hline Name & Code & $\begin{array}{l}\text { Democ- } \\
\text { racy Index } \\
\text { (1) }\end{array}$ & $\begin{array}{l}\text { Civil } \\
\text { Liberties } \\
(1)\end{array}$ & $\begin{array}{l}\text { Freedom in } \\
\text { the world } \\
\text { (2) }\end{array}$ & $\begin{array}{l}\text { Far-Right } \\
\text { Party (3) }\end{array}$ & $\begin{array}{l}\text { Net migration } \\
\text { (3) }\end{array}$ & $\begin{array}{l}\text { Foreign-born } \\
\text { residents (3) }\end{array}$ \\
\hline Austria & AT & 8.29 & 8.82 & 95 & 46.2 & 7.5 & 22 \\
\hline Belgium & $\mathrm{BE}$ & 7.78 & 8.53 & 95 & 3.67 & 2.4 & 20 \\
\hline Switzerland & $\mathrm{CH}$ & 9.03 & 9.12 & 96 & 0.5 & 4.7 & 39 \\
\hline Czech Republic & $\mathrm{CZ}$ & 7.69 & 8.53 & 94 & 35.4 & 1.9 & 4 \\
\hline Germany & $\mathrm{DE}$ & 8.68 & 9.41 & 95 & 12.64 & 5.6 & 15 \\
\hline Estonia & $\mathrm{EE}$ & 7.97 & 8.53 & 94 & 1.3 & 0.8 & 17 \\
\hline Spain & ES & 8.08 & 8.82 & 94 & 10.26 & 1.9 & 15 \\
\hline Finland & FI & 9.14 & 9.71 & 100 & 17.7 & 3.1 & 6 \\
\hline France & FR & 7.8 & 9.53 & 90 & 33.9 & 1 & 14 \\
\hline UK & GB & 8.53 & 9.12 & 95 & 30.5 & 3.8 & 15 \\
\hline Hungary & $\mathrm{HU}$ & 6.63 & 7.06 & 76 & 16.67 & -0.1 & 2 \\
\hline Ireland & $\mathrm{IE}$ & 9.15 & 10 & 96 & 0 & 5.2 & 20 \\
\hline Israel & IL & 7.79 & 5.88 & 80 & 26.46 & 2.2 & 26 \\
\hline Iceland & IS & 9.58 & 9.71 & 97 & 0.2 & 4.2 & 14 \\
\hline Italy & IT & 7.71 & 8.24 & 89 & 34.3 & 1.1 & 11 \\
\hline Lithuania & LT & 7.5 & 9.12 & 91 & 2.6 & -10.5 & 5 \\
\hline Netherlands & $\mathrm{NL}$ & 8.89 & 9.12 & 99 & 13.06 & 4.6 & 14 \\
\hline Norway & $\mathrm{NO}$ & 9.87 & 9.71 & 100 & 16.3 & 6.6 & 17 \\
\hline Poland & PL & 6.67 & 7.63 & 89 & 28.89 & 0.3 & 2 \\
\hline Portugal & $\mathrm{PT}$ & 7.84 & 9.12 & 97 & 0.34 & -0.8 & 9 \\
\hline $\begin{array}{l}\text { Russian Fed- } \\
\text { eration }\end{array}$ & RU & 2.94 & 3.24 & 20 & 5.65 & 1.7 & 8 \\
\hline Sweden & SE & 9.39 & 9.41 & 100 & 17.5 & 11.9 & 20 \\
\hline Slovenia & SI & 7.5 & 8.24 & 92 & 4.17 & 0.7 & 13 \\
\hline
\end{tabular}

(1) Indices range 1-10; (2) Index range 1-100; (3) Percentages

Source: Own elaboration

The scores are based on the analysis of 25 indicators: 10 for political rights and 15 for civil liberties (Freedom House, 2019). The political rights questions are grouped into three subcategories: Electoral Process (3 questions), Political Pluralism and Participation (4), and Functioning of Government (3). The civil liberties questions are grouped into four subcategories: Freedom of Expression and Belief (4 questions), Associational and Organizational Rights (3), Rule of Law (4), and Personal Autonomy and Individual Rights (4). The information is based on the 2019 edition.

The far-right party column includes the information of the success of the party in the last national election held in the country in which the analysis is limited to the most successful far-right party in each country. We identified the relevant far-right parties by relying in previous classifications (Immerzeel et al., 2016; Mudde, 2007; Szöcsik \& Polyakova, 2019). We deviate from Mudde's selection -as Immerzeel 
et al. (2016) and Szöcsik and Polyakova (2019) did-in that we also include neoliberal populist parties in our selection. Similarly to Szöcsik and Polyakova (2019), we also include Alternative for Germany (Alternative für Deutschland) and DawnNational Coalition (Občanská Demokratická Strana) in Germany and Czech Republic, respectively.

Net migration provides information obtained from Eurostat for the migration flow data for the year 2016. The migration flow is affected by a number of issues in which different labour bilateral agreements between countries and labour freemobility areas can be considered important key drivers. For example, immediately upon accession to the EU, the countries are obliged to facilitate labour insertion for other nationals of EU the new member countries. Switzerland entered into the freemobility zone of the EU between 2004 and 2007 in gradual steps (Jauer et al., 2019). Net migration is defined as the difference between the number of immigrants and the number of emigrants from a given year per one thousand inhabitants. Net migration is negative when the number of emigrants exceeds the number of immigrants. According to Eurostat, as some countries either do not have accurate figures on immigration or emigration, net migration is generally estimated on the basis of the difference between population change and natural increase between two dates, and it is then named as corrected net migration (EC, 2003).

And finally, the last column-foreign-born residents-measures in percentage the share of the residents who have born outside of the country. The share of foreign-born residents depends on two different issues: first, the number of immigrants, and, second, how difficult or easy is for the foreigners to achieve the full citizenship status of the countries which host them. An interesting example is observed in the USA where the dynamics is changing dramatically, as $80 \%$ of the foreigners were naturalized in the 1980s, and more recently, less than $40 \%$ of the foreigners obtained the American citizenship in 2000s. Bloemraad (2006) contended that this trend is explained by the shift of the origins of newcomers from Europe to Latin America and Asia. Some conjectures are also placed regarding the loyalty, the civic spirit and the interests in political participation of the new comers.

To measure the citizens' openness index towards immigration (COITI) and the citizens' openness index towards immigration and refugees (COITIR), the study relies mainly on the data from the European Social Survey (ESS) round 8 (version 2.0). The ESS includes stable and well-defined measurement scales that are related to citizens' migration attitudes (Messing \& Ságvári, 2018). These include measures of opposition to immigration (3 indicators), measures of economic, cultural life and place to live quality effects ( 3 indicators) and measures of opposition to refugees ( 3 indicators). At first glance, the idea is to build a synthetic openness immigrationrefugees indicator with the 9 indicators included in the ESS database. However, one of the three indicators of the opposition to refugees' scales is missing in the ESS data for Hungary. Individual indicators have typically been used on their own (Davidov et al., 2020; Green et al., 2019). However, the aim of our study is to estimate a composite indicator using all the indicators as components, as individual indicators usually provide partial and conflicting views of the phenomenon under study.

The opposition to immigration module is based on the following three questions: 'To what extent do you think [country] should allow people': (1) of the 
same race or ethnic group as most [country]'s people to come and live here?' [variable: imsmetn]; '(2) of a different race or ethnic group from most [country] people to come and live here?' [variable: imdfetn]; (3) 'from poorer countries outside Europe to come and live here?' [variable: impcntr]. The semantic scale is based on the following response options: (1) Allow many to come and live here; (2) Allow some; (3) Allow a few; and (4) Allow none. The immigration module constitutes a plausible index of opposition to immigration as, in our case, we are interested in measuring a composite indicator of openness to immigration attitude, the scale is reversed for the three indicators.

The three statements included in the measurement of the effects of immigration on the economy, the cultural life and the place to live quality are as follows: (1) Immigration bad or good for country's economy [variable: imbgeco]; (2) country's cultural life undermined or enriched by immigrants [variable: imueclt]; and (3) immigrants make country worse or better place to live [variable: imwbcnt]. The answer format for the three attributes is based on 11-points Likert scales anchored in the extreme points: 0 means bad, undermined or worse; and 10 means good, enriched or better. In this case, it is obvious that the scale presents a direct relationship with the openness to immigration scale, so the raw data do not need to be transformed.

And finally, the three statements included in the refugees' module are as follows: (1) governments should be generous judging applications for refugee status [variable: gvrfgap]; (2) most refugee applicants are not in real fear of persecution in the own countries [variable: rfgfrpc]; and (3) granted refugees should be entitled to bring close family members [variable: rfgbfml]. The answer format is based on a 5-points Likert scale (1. Agree strongly, 2. Agree, 3. Neither agree nor disagree, 4. Disagree, 5. Disagree strongly). In this case, the first and the third variables have an inverse relationship with the degree of agreement that citizens have on the ethical responsibility towards refugees. Meanwhile, the second variable presents a direct relationship as the question is presented with a negation of the real fear of persecution, so in this case 5 means that citizens think that most of the refugees' applicants are in real fear. Thus, the first and third variables are reversed.

Finally, in order to analyse whether political orientation affects the phenomenon under study, the answers to the question of citizen's placement on left-right scale [variable: lrscale] were also included in the database. The answer format is based on 11-points anchored scale in which 0 and 10 mean left and right, respectively. The variable is recoded into four different categories according to the following scheme: left (0-2), centre-left (3-5), centre-right (5-7), and right (8-10). As said, the political orientation scale is divided into eleven categories, so we preferred to include the median value 5 into two categories centre-left and centre-right. Political orientation is important as immigration has been depicted by many right-wing parties as the central danger against the social welfare and quality of life of true national citizens, so anti-immigration sentiments can explain, in part, right-wing voting (Bello, 2016; Davidov et al., 2020; de Vreese, 2017; Gorodzeisky, 2011; Kunovich, 2004; Semyonov \& Glikman, 2009). 


\section{Methodology}

Composite indicators (CIs) are usually prescribed when researchers analyse some phenomenon that has a multidimensional nature. Mendola and Volo (2017) propose 15 criteria that researchers need to look at when they develop CIs. Among the 15 criteria, two of them (11 and 12), the weighting method to aggregate the individual indicators and the aggregation method, are considered crucial. In the literature of CIs, the simple average or other functional forms based on equal weights are considered unweighted indicators.

On the other hand, Data Envelopment Analysis (DEA) obtains the weights of the individual indicators endogenously (Charnes et al., 1978) without any human interaction that can contaminate the weights spuriously. In addition, the weights are obtained through the Benefit-of-the-Doubt (BoD) principle (Cherchye et al., 2007) which means that every individual observation weights are obtained in order to rank each observation as high as possible. DEA is a non-parametric technique developed to measure production efficiency that was proposed in the 1970s by Charnes and his colleagues. Basically, a linear mathematical program is resolved iteratively to obtain the efficiency indicator for a sample of decision-making-units (DMUs), in which the vector of inputs and outputs of each unit are compared with a linear combination of the vectors of inputs and outputs observed in the sample. Different assumptions about the flexibility of the linear combinations as well as the orientation result in different DEA models. Cooper et al. (2007) can be consulted to have more information of the different existing DEA methods.

The first issue to consider is whether the partial indicators are inputs or outputs, and, normally, the following convention applies: inputs (the less, the better) and outputs (the more, the better). In some cases, input or output vectors do not exist, then researchers need to create a dummy output vector equal to one (or input) to apply a DEA model with the rest of inputs (or outputs) (Lovell et al., 1995; Zhou et al., 2007).

Our case study is based in two different scales: 6 immigration openness indicators and 9 individual indicators in which the three refugees' openness indicators have been added to the previous scale. The DMUs or observations are based on the country average figures and the country-political orientation average figures. Thus, assuming that $i$ represents the individual partial indicators and $d$ represents the population segments, the mathematical program that calculates the synthetic indicator for each of the scales is as follows:

$$
\begin{gathered}
S I_{d}=\begin{array}{c}
\operatorname{Max}_{w_{i d}} \sum_{v=1}^{n} w_{i d} \text { Ind }_{i d} \\
\text { Subject to : }
\end{array} \\
\sum_{v=1}^{n} w_{i d} \text { Ind }_{i d} \leq 1 ; d=1 \cdots D ; i=1 \cdots n ; w_{i d} \geq 0
\end{gathered}
$$

Where $I n d_{i d}$ is the figure of the partial indicator $i$ in each of the scales for the population segment $\mathrm{d}$; and $w_{i d}$ is the weight obtained for the partial indicator $i$ in the SI of the population segment $d$. Furthermore, the indicators obtained from (1) are normalised to one, so that the larger the score, the population segment $d$ is more 
open to immigrants. As previously said, the main feature of DEA methods is that the weights obtained for each individual indicator are endogenously determined at the population segment level. Moreover, in line with the abovementioned BoD principle, these weights - which by construction are idiosyncratic - are calculated so as to maximise the respective composite indicators when the frontier is made considering all the population segments assessed according to the same scheme (Cherchye et al., 2007). The BoD principle is one of the main advantages presented by DEA in comparison with other multiple multi-criteria decision making methods that can be used to obtain CIs. Some other methods are based on obtaining exogenous weights using expert opinions through well documented practices like Analytic Hierarchy Process [AHP] (Saaty, 1990) and Delphi methodologies (Linstone \& Turoff, 2002).

The model in Eq. 1 is applied for two different scenarios that correspond to the two scales under study: immigration (6 indicators) and immigration-refugees (9 indicators). Regarding $D$, the number of population segments, the number of DMUs is equal to 115 that corresponds to the 23 countries which participated in ESS8 (Austria, Belgium, the Czech Republic, Estonia, Finland, France, Germany, Hungary, Iceland, Ireland, Israel, Italy, Lithuania, the Netherlands, Norway, Poland, Portugal, Russian Federation, Slovenia, Spain, Sweden, Switzerland, and the UK) times 5 population segments obtained through the political orientation variable (left, centre-left, centre-right, right and all the citizens).

\section{Results}

\section{Immigrants and Refugees}

We present and discuss the results obtained with our model for the two commented scenarios. First, it can be seen in Table 2, that despite of the refugees' crisis in 2015/16, the inclusion of the three indicators of the refugees' module seems not to affect the openness attitude towards immigration and refugees. In fact, all the countries seem to be more open in relative terms when the refugees' indicators are included with the exception of the five following countries: Switzerland, Germany, Estonia, Israel, and Iceland. In these countries, including the refugees' attitudes does not change the immigration index. This result was not expected as, according to Heath and Richards (2019), there was marked shift in negative direction after the 2015/16 refugee crisis of the government policy towards refugees. The refugee crisis was characterized by large flows of asylum seekers coming from war-torn Syria, Afghanistan, Iran and other African countries. 'Countries such as Austria, Germany and Sweden which had experienced large inflows of refugees showed particularly large declines in public support for generous government policy with respect to the treatment of asylum requests (p.4)'. Nevertheless, as we analyse below, the relative position of the most and the least open countries changes and depends on whether the refugees' information is included or not.

The analysis of each index serves to conclude that regarding immigration, the following countries are the most open: Iceland, Sweden, Germany, Finland, and Israel. On the other hand, the following countries are the least open: Austria, Russian 
Table 2 DEA Immigration and DEA Immigration-Refugees Openness Indices

\begin{tabular}{|c|c|c|}
\hline Country & $\begin{array}{l}\text { DEA Immigration } \\
\text { openness index }\end{array}$ & $\begin{array}{l}\text { DEA Immigration- } \\
\text { Refugees openness } \\
\text { index }\end{array}$ \\
\hline Austria & 0.728 & 0.740 \\
\hline Belgium & 0.808 & 0.840 \\
\hline Switzerland & 0.850 & 0.850 \\
\hline Czech Republic & 0.607 & 0.708 \\
\hline Germany & 0.894 & 0.894 \\
\hline Estonia & 0.786 & 0.786 \\
\hline Spain & 0.841 & 0.944 \\
\hline Finland & 0.886 & 0.928 \\
\hline France & 0.796 & 0.856 \\
\hline UK & 0.803 & 0.815 \\
\hline Hungary & 0.659 & NA \\
\hline Ireland & 0.823 & 0.850 \\
\hline Israel & 0.861 & 0.861 \\
\hline Iceland & 0.955 & 0.955 \\
\hline Italy & 0.712 & 0.803 \\
\hline Lithuania & 0.736 & 0.797 \\
\hline Netherlands & 0.797 & 0.843 \\
\hline Norway & 0.848 & 0.899 \\
\hline Poland & 0.739 & 0.832 \\
\hline Portugal & 0.812 & 0.926 \\
\hline Russian Federation & 0.720 & 0.770 \\
\hline Sweden & 0.920 & 0.921 \\
\hline Slovenia & 0.788 & 0.802 \\
\hline
\end{tabular}

Source: Own elaboration

Federation, Italy, Hungary and Czech Republic. The rest of the countries included in the analysis are in between. Our results are concordant with those obtained by Heath and Richard (Heath \& Richards, 2019). The authors found that in general Nordic countries such as Sweden, Norway and Finland have been consistently the most favourable to immigration while eastern European countries such as the Czech Republic and Hungary have been the least favourable (p. 4)'. Our index concludes that Norway occupies the seventh position regarding the most favourable attitude towards immigrants.

When we include the refugees' dimension, it can be seen that the most open countries are: Iceland, Spain, Finland, Portugal and Sweden. Meanwhile, the least open countries are: Lithuania, Estonia, Russian Federation, Austria and Czech Republic. An important difference exists when the analysis is done including the refugees' variables, as now, Portugal and Spain, the countries of the Iberian Peninsula join the Nordic countries as the most favourable to immigrants and refugees. In the case of Spain, it is highly probable that the public media have played a proactive role 
in changing the negative refugees' vision. In addition, the role of activists of some NGOs, especially those directly involved in humanitarian tasks either on the Mediterranean Sea or in refugee campgrounds, has also contributed to raise awareness of the need to not criminalize the refugees' image.

On the other hand, the results for the least open countries have not changed much as the countries belong to the sphere of the old Soviet Republics, Austria, and Czech Republic. The results are explained in part by the anti-resettlement consensus that exist in some of the new Eastern member states of the EU (Ágh, 2016). A decisive turning point appeared after the Balkan Route crisis that precipitated Merkel's government temporary decision to lift existing EU immigrant and refugees' restrictions. The important solidarity gesture caused a huge number of political tensions that precipitated new more restrictive immigration and refugees' policies (Crage, 2016). According to Park (2015), Berlin swiftly started asking for co-responsibilities in terms of mandatory migrant relocation quotas which elevated immigration policies in the core of EU politics. Provisional measures were adopted for the benefit of Italy and of Greece, but not without many Central and Eastern countries' objections. In fact, Czech Republic, Hungary and Slovakia voted against these measures. Unfortunately, it was not possible to include Hungary in the analysis for the commented problem of the missing variables, but it is highly probable that the country had been in the set of the least open countries to immigrants and refugees.

\section{Political Orientation}

Heath and Richards (2019) contend that immigration was, is, and will be one of the most important affairs in the political agenda in Brussels. Anti-immigration sentiment is growing in many European countries and far-right political parties as the main advocates of policies aligned with this sentiment are entering in many National Parliaments and the EU Parliament. In a similar way, Capelos and Katsanidou (2018) analysed how the concurrent waves of anti-EU integration and anti-immigration, dormant cultural fears, suspicious towards international institutions and general politics could explain the changes on political preferences that could cause political disengagement, violent protests and more votes for populist and anti-establishment parties.

Table 3 shows how political orientation affects to COITIR. Thus, it can be seen that the most open population segments are as follows: Spain(Left), Iceland(Left), Norway(Left), Finland(Left), Sweden(Left), France(Left), Switzerland(Left), Israel(Right), Iceland(Left-Centre), Spain(Left-Centre), UK(Left), Iceland(Right-Centre), Portugal(Left), Netherlands(Left), Austria(Left). Meanwhile, the least open population segments are: Austria(Left-Centre), Russian Federation(Left-Centre), Netherlands(Right), Russian Federation(Right-Centre), Slovenia(Right), Switzerland(Right), France(Right), UK(Right), Italy(Right), Czech Republic(Right-Centre), Czech Republic(Left-Centre), Austria(Right-Centre), Czech Republic(Right), Czech Republic(Left), Austria(Right).

In Table 3, it can also be seen that the general trend for the majority of the countries is that leftist are more open to immigrant and refugees than left-centrist; left-centrist are more open than right-centrist; and right-centrist are more 
Table 3 DEA ImmigrationRefugees Openness Index by political orientation

\begin{tabular}{|c|c|c|c|c|}
\hline Country & Left & Left-Centre & Right-Centre & Right \\
\hline Austria & 0.933 & 0.766 & 0.707 & 0.581 \\
\hline Belgium & 0.877 & 0.847 & 0.823 & 0.773 \\
\hline Switzerland & 0.975 & 0.862 & 0.820 & 0.758 \\
\hline Czech Republic & 0.654 & 0.711 & 0.720 & 0.705 \\
\hline Germany & 0.932 & 0.896 & 0.868 & 0.845 \\
\hline Estonia & 0.780 & 0.775 & 0.773 & 0.823 \\
\hline Spain & 1.000 & 0.956 & 0.915 & 0.838 \\
\hline Finland & 0.998 & 0.926 & 0.919 & 0.909 \\
\hline France & 0.987 & 0.876 & 0.822 & 0.745 \\
\hline UK & 0.952 & 0.824 & 0.791 & 0.743 \\
\hline Ireland & 0.878 & 0.861 & 0.850 & 0.808 \\
\hline Israel & 0.865 & 0.823 & 0.889 & 0.973 \\
\hline Iceland & 1.000 & 0.964 & 0.948 & 0.917 \\
\hline Italy & 0.899 & 0.815 & 0.791 & 0.721 \\
\hline Lithuania & 0.840 & 0.769 & 0.782 & 0.868 \\
\hline Netherlands & 0.934 & 0.865 & 0.823 & 0.764 \\
\hline Norway & 1.000 & 0.913 & 0.879 & 0.831 \\
\hline Poland & 0.872 & 0.830 & 0.814 & 0.832 \\
\hline Portugal & 0.945 & 0.923 & 0.907 & 0.928 \\
\hline Russian Federation & 0.797 & 0.765 & 0.763 & 0.795 \\
\hline Sweden & 0.997 & 0.930 & 0.907 & 0.862 \\
\hline Slovenia & 0.875 & 0.807 & 0.780 & 0.759 \\
\hline
\end{tabular}

Source: Own elaboration

open than rightist. Czech Republic and Israel are the main exceptions to the general rule. It is not easy to find a tentative explanation to these observed exceptions, but maybe, for the case of Israel, the explanation can be found in the own migrant composition of the country.

Another possible explanation can be rooted in the own history of the country in which the Law of Return enables free immigration and grants immediate citizenship to immigrants. The case of Czechia can be better explained by the fact that all the segments are more homogeneous, and as we will analyse below Czechs, independently of the political orientation, are among the least favourable segments to immigration and refugees.

Analysing the 15 most favourable segments, it can be seen that most of them (11) belong to some country leftist group. The four exceptions-Israel(Right), Iceland(Left-Centre), Spain(Left-Centre) and Iceland(Right-Centre)—can be explained by the special characteristics of Spain, Iceland and Israel. In the case of Iceland, the most open country to immigrants and refugees, it is evident that the citizens are more homogeneous. The case of Spain can be partly explained by the already commented media positioning of not criminalizing the refugees and the movement of opinion in some important municipalities of Spain towards 
'welcome refugees'. In any case, it can be concluded that the most favourable segments are clearly characterized by the political orientation.

Regarding the 15 least favourable segments, there are now 8 rightist segments. The seven non-rightist segments-Austria(Left-Centre), Russian Federation(LeftCentre), Russian Federation(Right-Centre), Czech Republic(Right-Centre), Czech Republic(Left-Centre), Austria(Right-Centre), and Czech Republic(Left)—are characterized for being segments of Austria, Russian Federation and Czech Republic which are the countries least favourable towards immigration and refugees.

\section{Analysis of the Relationship Between COITIR and Other Variables}

Figure 1 shows the plots that can be used to see at first glance the existing type of relationship between COITIR and the six variables included in Table 1: Democracy index, Civil liberties, Freedom in the world, Far-Right party representativeness, Net migration and Foreign-born residents. The plot pretends to give a first visualization of the relationship, and for that, COITIR represents the response variable on the $\mathrm{y}$ axis and the six variables are seen as explanatory variables on the $\mathrm{x}$ axis. In

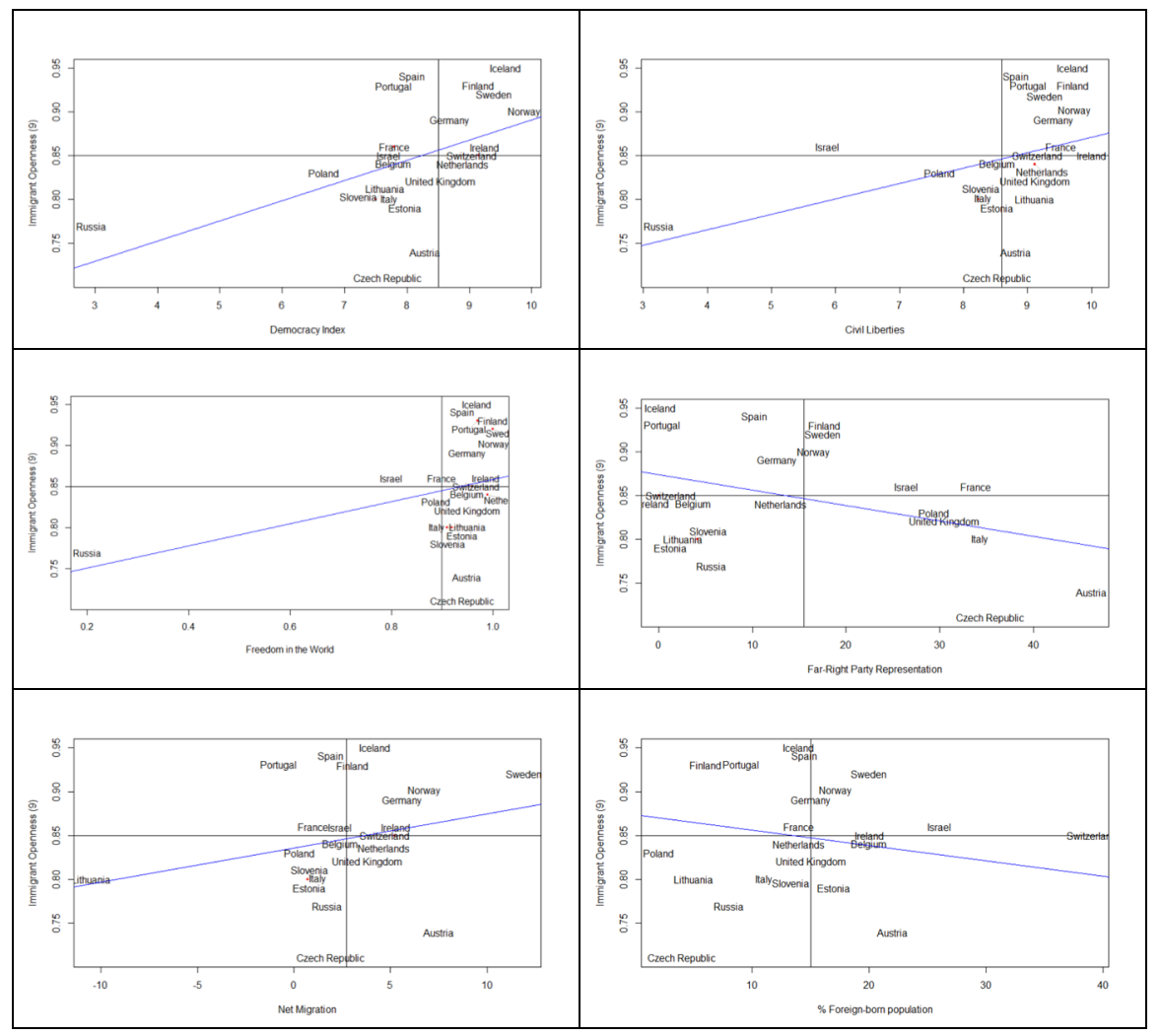

Fig. 1 Relationship between immigration-refugees openness index and other variables 
all the cases and given the nature of COITIR, scatterplots with the average values of both variables are represented by vertical and horizontal lines. Thus, there are four regions in the plot that are going to be explained from quadrant I to quadrant IV moving anti-clockwise: quadrant $\mathrm{I}(>,>)$ is characterized by countries with observations greater than the average values for both variables include in the analysis; quadrant II $(<,>)$ is characterized because the countries are more open than the average country but the values of the variable are lower than the average; quadrant III $(<,<)$ is characterized by countries with observations lower than the average values; and quadrant IV $(>,<)$ is characterized because the countries are less open than the average country and the values of the variables are greater than the average.

The relationship is analysed with the linear regression line represented in the plot. Thus, it is very simple to see which countries depart more from the general trend when there exists a positive relationship (quadrants II and IV) or when there exists a negative relationship (quadrants I and III).

The figure shows that there exists a positive relationship between COITIR and Democracy index (left plot of first row), Civil liberties (right plot of first row), Freedom in the world (left plot of second row) and Net migration (left plot of third row). Meanwhile, the existing relationship is negative with Far-right party representativeness (right plot of second row) and foreign-born residents (right plot of third row).

The plots of the relationship between COITIR and democracy index, civil liberties and freedom in the world show some similarities. It can be seen that the first quadrant is characterized by the Nordic countries-Finland, Sweden, and Norwayand Iceland. Nevertheless, the good results of these countries present also some grey areas. The analysis is based on the report of the freedom in the world 2017 (Freedom House, 2017). In Finland, the number of new asylum seekers decreased in 2016, but the government decided to tighten asylum laws during the year. In Sweden, asylum seekers in 2015 and 2016 led to political tensions as well as a strain on government resources. The asylum influx led to a number of reversals in both policies and attitudes, and in 2016, officials aligned asylum regulations with the minimum standards set by the EU. In Norway, the continued influx of refugees and other migrants dominated the political debate in 2015 and 2016. The government passed a more stringent law that restricted access to asylum. Norway has also been criticized for violating the principle of non-refoulement in the border with Russia. The second quadrant is not uniform and some countries entered into the quadrant and left it depending on each variable. The third quadrant is mainly characterized by Russia and Czechia. Russia is world widely known by its restrictive political atmospherepress freedom does not exist and the state controls the flow of information, there are important limitations on activism, and hostility to opposition is highly exerted with fraudulent electoral results. In $2016,70 \%$ of the economy is still centralized either directly or through state-owned enterprises. Immigrants and ethnic minorities-particularly those who appear to be from the Caucasus or Central Asia—suffer from discrimination, and the government restricts freedoms of movement and residence, limiting the place of residence to specific minorities and migrants from the Caucasus and Central Asia. In Czechia, several rallies in contra of the acceptance and integration of refugee and immigrant communities were common throughout 2016. Anti-immigrant, anti-refugees, and anti-Islamic sentiment is persistent in the 
Czech Republic. In addition, asylum seekers are routinely detained, and conditions in detention centres are generally poor.

The causality of the observed negative relationship between COITIR and the representativeness of far-right parties is still being investigated. In fact, Dennison and Geddes (2019) showed that the commonly assumed reason for the representativeness increase is not necessarily associated with an increase in anti-immigration attitude. Nevertheless, the right centred plot shows that quadrant I contains Finland, Sweden, Norway, France and Israel. Iceland, Spain, Portugal, Germany and Switzerland lay in the quadrant II. Quadrant III contains Ireland, Belgium, Netherlands, Slovenia, Lithuania, Estonia and Russia. And, quadrant IV contains Poland, UK, Italy, Austria, and Czechia. According to Dennison and Geddes (2019), the anti-immigration sentiment existed already within a shrinking segment of the population of some European states. Nevertheless, the existing credo of a rising tide of anti-immigration sentiment that apparently swept the core of the EU was the resultant from negative and hostile media coverage of immigration and migrants. The authors showed that these two arguments are totally questionable. First, there is little evidence that anti-immigration is sweeping Europe. In fact, the authors contended that, counterintuitively, a more favourable sentiment appeared during and since the 'migration crisis' of 2015. Regarding the relevance of negative media coverage of migrants and asylum-seekers, attitudes to migration do not change that much because as any other attitude to other political issues, attitudes to migrants 'are primarily formed relatively early in life and linked to key formative experiences such as education (p.108).'

Regarding net migration (left bottom plot), it can be seen that quadrant I-more positive attitude to immigrants and refugees than average and a higher net migration rate than average-contains the following countries: Iceland, Sweden, Norway, Germany, and Ireland. These countries are characterized by low unemployment rates and are net receptors of immigrants who searched better labour market conditions. Portugal, Spain, Finland, France, and Israel lay in the quadrant II which is regarded as the area with a more favourable attitude to immigrants and refugees, and a lower net migration rate than the average. It is well known that the financial crisis of 2008 affected very much to Portugal and Spain, so both countries displayed low levels of immigration numbers in recent years. In fact, the sovereign debt crisis coupled with austerity policies affected the southern periphery of the EU-Spain, Italy, Portugal, and Greece-exacerbating the emigration phenomenon (Pereira \& Azevedo, 2019). The quadrant III is formed by those countries that have a lower attitude towards immigrant and refugees, and a lower net emigration rate than the average. The following countries are in this area: Lithuania, Poland, Estonia, Czech Republic, Slovenia, Russia, UK, Belgium, and Italy. And finally, there are only three countries, Netherlands, Switzerland, and Austria, which constitute the quadrant IV, the area in which the countries have a lower favourable attitude to immigrants and refugees and a higher net migration rate than the average. In this case, it is likely that many of these migrants were citizens from new EU member states (Arpaia et al., 2016), as east-west migration in the free-mobility area in Europe was accelerated with the EU enlargements in 2004 and 2007 (Kahanec \& Pytliková, 2017). 
And finally, analysing the relationship of COITIR with the share of foreign-born residents (right bottom plot), it can be seen that quadrant I is formed by Sweden, Norway, Germany, Ireland, Israel and Switzerland. The quadrant II contains Iceland, Spain, France, Finland and Portugal. The quadrant III is formed by Czechia, Poland, Lithuania, Russia, Italy, Slovenia, UK, and Netherlands. And quadrant IV only contains Belgium, Estonia and Austria. Previous research shows that people commonly exaggerate the size of foreign-born residents. Hopkins et al. (2019) contended that Americans are prone to exaggerate the size of foreign-born residents-much as they exaggerate the size of other minority groups - and these misperceptions are the cause of unfavourable attitudes to immigration. The findings suggest that attitudes toward immigration do not change much and are quite stable and resistant to information as they were established early in life and reinforced by later socialization (Hainmueller \& Hopkins, 2014). Theories of inter-group power threat predict that the cognitive mechanism could be affected by misperceptions about how large the minority groups. Nevertheless, Hopkins et al. (2019) results are concordant with previous research (Wong, 2007) as the correction of the subjective misperceptions of the size of the minority groups seems not to alter attitudes about the minority group.

In summary, net migration and the size of foreign-born residents have made national citizens of the majority group more sensitive to threats from migration and this has caused an increase in anti-immigration sentiments. For example, "in Britain, public preferences for less immigration have been among the drivers of the British immigration policy, including restrictions aimed at reaching a numerical target for estimated annual net migration. The government has explicitly claimed that its motivation to reduce the number of immigrants coming to Britain is a response to public opinion, tying its drive to reduce net migration to public concern about immigration (Dalla Valle et al., 2020) (p. 425).”

\section{Conclusions}

The paper introduces a method based on DEA to provide two composite indicators that measure the citizens' openness to immigration and to immigration and refugees. The interest for the topic has grown significantly for academics, policymakers, and the general public. A better understanding of the phenomenon is crucial for the development of suitable social and political immigration policies at national level. In addition, a common vision and foreseeable strategies will be essential to the success of the European Union's ideal of a new global consciousness that unites the EU's nation-states, European dreams and actions for humanity.

The ESS round 8 is used to analyse the openness towards immigration and refugees of 23 countries, 17 EU Countries, plus Iceland, Israel, Norway, Switzerland, Russia, and the UK, using 9 individual indicators. In the case of immigration, the number of indicators is reduced to six, and Hungary is also included in the analysis. The results show that Iceland, Nordic countries, Spain, and Portugal are more open towards immigrants and refugees than other countries in the sample. The analysis is also extended to see whether political orientation has an effect on COITIR, and 
results seem to confirm that leftist are in general more open than the rest of political orientation groups. Nevertheless, in the least open population segments, the results show that, for some countries -especially Czechia- citizens are less open independently of the political orientation. Interesting insights are also obtained analysing the relationship between COITIR and other variables related with democracy, civil liberties, net migration, far-right parties' representativeness, and foreign-born residents. The results show that the relationship varies between countries and variables. The proposed composite indicators serve to provide the citizens' attitude towards immigration and refugees, a topic that is currently of great importance for academics, politicians and public in general. Developing suitable social and political immigration strategies will be crucial for the failure or success of the EU dream.

As any other study, there are some important limitations. First, the study is only static and it is based on the round 8 of the ESS. It would be interesting to contrast dynamically the evolution of the indicators using some other rounds of the survey. The number of countries is also limited by the survey constraints and other geographical areas are clearly misrepresented. Another venue for future research is to analyse some specifics about the immigrants such as low-skilled or high-skilled. And finally, the indicators can be estimated for other important covariates such as income, gender, education and religion, among others.

Acknowledgements We have benefited from many colleagues' comments, suggestions, discussions and assistance. The usual disclaimer applies.

Funding Open Access funding provided thanks to the CRUE-CSIC agreement with Springer Nature.

\section{Declarations}

Conflict of Interest The authors declare no competing interests.

Open Access This article is licensed under a Creative Commons Attribution 4.0 International License, which permits use, sharing, adaptation, distribution and reproduction in any medium or format, as long as you give appropriate credit to the original author(s) and the source, provide a link to the Creative Commons licence, and indicate if changes were made. The images or other third party material in this article are included in the article's Creative Commons licence, unless indicated otherwise in a credit line to the material. If material is not included in the article's Creative Commons licence and your intended use is not permitted by statutory regulation or exceeds the permitted use, you will need to obtain permission directly from the copyright holder. To view a copy of this licence, visit http://creativecommons.org/licen ses/by/4.0/.

\section{References}

Ágh, A. (2016). The core-periphery divide in the EU transformation crisis: challenges to the Visegrád Four. Rocznik Instytutu Europy Środkowo-Wschodniej, 14(2), 113-130.

Allport, G. W., Clark, K., \& Pettigrew, T. (1954). The nature of prejudice.

Arpaia, A., Kiss, A., Palvolgyi, B., \& Turrini, A. (2016). Labour mobility and labour market adjustment in the EU. IZA Journal of Migration, 5(1), 1-21.

Balcilar, M., \& Nugent, J. B. (2019). The migration of fear: An analysis of migration choices of Syrian refugees. The Quarterly Review of Economics and Finance, 73, 95-110. 
Barreto, M. I., Borja, H., Serrano, Y., \& López, W. L. (2009). La legitimación como proceso en la violencia política, medios de comunicación y construcción de culturas de paz. Universitas Psychologica, $8(3), 737-748$.

Bello, V. (2016). Inclusiveness as Construction of Open Identity: How social relationships affect attitudes towards immigrants in European Societies. Social Indicators Research, 126(1), 199-223.

Berg, J. A. (2010). Race, class, gender, and social space: Using an intersectional approach to study immigration attitudes. The Sociological Quarterly, 51(2), 278-302.

Berg, J. A. (2015). Explaining attitudes toward immigrants and immigration policy: A review of the theoretical literature. Sociology Compass, 9(1), 23-34.

Berry, M., Garcia-Blanco, I., \& Moore, K. (2015). Press coverage of the refugee and migrant crisis in the EU: A content analysis of five European countries: Report prepared for the United Nations High Commission for Refugees. Cardiff School of Journalism, Media and Cultural Studies.

Bloemraad, I. (2006). Becoming a citizen: Incorporating immigrants and refugees in the United States and Canada. University of California Press, Ltd.

Braun, R. (2011). The diffusion of racist violence in the Netherlands: Discourse and distance. Journal of Peace Research, 48(6), 753-766.

Capelos, T., \& Katsanidou, A. (2018). Reactionary Politics: Explaining the Psychological Roots of Anti Preferences in European Integration and Immigration Debates. Political Psychology, 39(6), 1271-1288.

Charnes, A., Cooper, W. W., \& Rhodes, E. (1978). Measuring the efficiency of decision making units. European journal of operational research, 2(6), 429-444.

Cherchye, L., Moesen, W., Rogge, N., \& Van Puyenbroeck, T. (2007). An introduction to 'benefit of the doubt'composite indicators. Social indicators research, 82(1), 111-145.

Cohrs, J. C., \& Stelzl, M. (2010). How ideological attitudes predict host society members' attitudes toward immigrants: Exploring cross-national differences. Journal of Social Issues, 66(4), 673-694.

Cooper, W. W., Seiford, L. M., \& Tone, K. (2007). Data Envelopment Analysis. A comprehensive text with models, applications, references and DEA-Solver software. Springer.

Crage, S. (2016). The more things change... developments in German practices towards asylum seekers and recognised refugees. German Politics, 25(3), 344-365.

Dalla Valle, L., Leisen, F., Rossini, L., \& Zhu, W. (2020). Bayesian analysis of immigration in Europe with generalized logistic regression. Journal of Applied Statistics, 47(3), 424-438.

Davidov, E., Seddig, D., Gorodzeisky, A., Raijman, R., Schmidt, P., \& Semyonov, M. (2020). Direct and indirect predictors of opposition to immigration in Europe: individual values, cultural values, and symbolic threat. Journal of Ethnic and Migration Studies, 46(3), 553-573.

de Vreese, C. H. (2017). How changing conditions make us reconsider the relationship between immigration attitudes, religion and EU attitudes. European Union Politics, 18(1), 137-142.

Dennison, J., \& Geddes, A. (2019). A rising tide? The salience of immigration and the rise of anti-immigration political parties in Western Europe. Political Quarterly, 90(1), 107-116.

EC. (2003). Demographic statistics: Definitions and methods of collection in 31 European Countries. Office for Official Publications of the European Communities.

EIU. (2019). Democracy Index 2018: Me too? Political Participation, Protest and Democracy. Economist Intelligence Unit.

Espenshade, T. J. (1995). Unauthorized immigration to the United States. Annual Review of Sociology, 21(1), 195-216.

ESS. (2018). ESS Round 8: European Social Survey. ESS-8 2016 Documentation Report. ESS ERIC.

European Commission (2020). Statistics on migration to Europe.

European Parliament (2017) EU migrant crisis: Facts and figures. Available online at: http://www.europ arl.europa.eu/news/en/headlines/society/20170629STO78630/eu-migrant-crisis-facts-and-figures. (Accessed on 01 September 2021).

Freedom House. (2017). Freedom in the World 2017 The Annual Survey of Political Rights and Civil Liberties Arch. Rowman and Littlefield Publishers.

Freedom House. (2019). Freedom in the world 2019. Democracy in retreat. Rowman and Littlefield Publishers.

Geddes, A., \& Scholten, P. (2016). The politics of migration and immigration in Europe. Sage Publications Ltd.

Gorodzeisky, A. (2011). Who are the Europeans that Europeans prefer? Economic conditions and exclusionary views toward European immigrants. International Journal of Comparative Sociology, 52(12), 100-113. 
Grande, E., Schwarzbözl, T., \& Fatke, M. (2019). Politicizing immigration in Western Europe. Journal of European Public Policy, 26(10), 1444-1463.

Greco, F., \& Polli, A. (2020). The political debate on immigration in the election campaigns in Europe. In A. Przegalinska, F. Grippa, \& P. Gloor (Eds.), Digital Transformation of Collaboration. Proceedings of the 9th International COINs Conference (pp. 111-124). Springer.

Green, E. G., Visintin, E. P., Sarrasin, O. and Hewstone, M. (2019). When integration policies shape the impact of intergroup contact on threat perceptions: a multilevel study across 20 European countries. Journal of Ethnic and Migration Studies, 1-18.

Green-Pedersen, C., \& Mortensen, P. B. (2015a). Avoidance and engagement: issue competition in multiparty systems. Political Studies, 63(4), 747-764.

Green-Pedersen, C., \& Mortensen, P. B. (2015b). Avoidance and engagement: issue competition in multiparty systems. Political Studies, 63(4), 747-764.

Hainmueller, J., \& Hopkins, D. J. (2014). Public attitudes toward immigration. Annual Review of Political Science, 17, 225-249.

Hawley, G. (2011). Political threat and immigration: Party identification, demographic context, and immigration policy preference. Social Science Quarterly, 92(2), 404-422.

Heath, A., \& Richards, L. (2019). How do Europeans differ in their attitudes to immigration?: Findings from the European Social Survey 2002/03-2016/17. OECD Social, Employment and Migration Working Papers No. 222. Paris: OECD.

Hopkins, D. J., Sides, J., \& Citrin, J. (2019). The muted consequences of correct information about immigration. The Journal of Politics, 81(1), 315-320.

Immerzeel, T., Lubbers, M., \& Coffé, H. (2016). Competing with the far right: Distances between the European far right and other parties on typical far right issues. Party Politics, 22(6), 823-834.

Ivarsflaten, E. (2005a). The vulnerable populist right parties: No economic realignment fuelling their electoral success. European Journal of Political Research, 44(3), 465-492.

Ivarsflaten, E. (2005b). The vulnerable populist right parties: No economic realignment fuelling their electoral success. European Journal of Political Research, 44(3), 465-492.

Jauer, J., Liebig, T., Martin, J. P., \& Puhani, P. A. (2019). Migration as an adjustment mechanism in the crisis? A comparison of Europe and the United States 2006-2016. Journal of Population Economics, 32(1), 1-22.

Kahanec, M., \& Pytliková, M. (2017). The economic impact of east-west migration on the European Union. Empirica, 44(3), 407-434.

Keeling, D. (1999). The transportation revolution and transatlantic migration, 1850-1914. Research in Economic History, 19, 39-74.

Kunovich, R. M. (2004). Social structural position and prejudice: An exploration of cross-national differences in regression slopes. Social Science Research, 33(1), 20-44.

Linstone, H. A., \& Turoff, M. (2002). The Delphi method. Addison-Wesley Pub.

Lovell, C. K., Pastor, J. T., \& Turner, J. A. (1995). Measuring macroeconomic performance in the OECD: A comparison of European and non-European countries. European journal of operational research, 87(3), 507-518.

Mendola, D., \& Volo, S. (2017). Building composite indicators in tourism studies: Measurements and applications in tourism destination competitiveness. Tourism Management, 59, 541-553.

Messing, V., \& Ságvári, B. (2018). Looking behind the culture of fear. Cross-national analysis of attitudes towards migration, Bonn, FES-Friedrich Ebert Stiftung < https://bit. ly/34iSvcs.

Mudde, C. (2007). Populist radical right parties in Europe. Cambridge University Press.

Park, J. (2015). Europe's migration crisis (pp. 311-325). Council of Foreign Relations.

Pereira, C., \& Azevedo, J. (2019). The fourth wave of Portuguese emigration: Austerity policies, European peripheries and postcolonial continuities. In C. Pereira \& J. Azevedo (Eds.), New and Old Routes of Portuguese Emigration (pp. 1-26). Springer.

Ravenstein, E. G. (1885). The laws of migration. Journal of the statistical society of London, 48(2), 167-235.

Ravenstein, E. G. (1889). The laws of migration. Journal of the royal statistical society, 52(2), 241-305.

Rocha, R. R., Longoria, T., Wrinkle, R. D., Knoll, B. R., Polinard, J. L., \& Wenzel, J. (2011). Ethnic context and immigration policy preferences among Latinos and Anglos. Social Science Quarterly, 92(1), 1-19.

Rydgren, J. (2008). Immigration sceptics, xenophobes or racists? Radical right-wing voting in six West European countries. European Journal of Political Research, 47(6), 737-765. 
Saaty, T. L. (1990). How to Make a Decision: The Analytic Hierarchy Process. European Journal of Operational Research, 48, 9-26.

Sanchez, G. R. (2006). The role of group consciousness in political participation among Latinos in the United States. American Politics Research, 34(4), 427-450.

Semyonov, M., \& Glikman, A. (2009). Ethnic residential segregation, social contacts, and anti-minority attitudes in European societies. European Sociological Review, 25(6), 693-708.

Semyonov, M., Raijman, R., \& Gorodzeisky, A. (2006a). The rise of anti-foreigner sentiment in European societies, 1988-2000. American sociological review, 71(3), 426-449.

Semyonov, M., Raijman, R., \& Gorodzeisky, A. (2006b). The rise of anti-foreigner sentiment in European societies, 1988-2000. American sociological review, 71(3), 426-449.

Shapira, H. (2013). Waiting for Jose: The Minutemen's Pursuit of America. Princeton University Press.

Simon, D. (1985). Agrarian policy and migration in Zimbabwe and Southern Africa: reform or transportation?.

Slominski, P., \& Trauner, F. (2018). How do member states return unwanted migrants? The strategic (non-) use of 'Europe'during the migration crisis. JCMS. Journal of Common Market Studies, 56(1), 101-118.

Szöcsik, E., \& Polyakova, A. (2019). Euroscepticism and the electoral success of the far right: the role of the strategic interaction between center and far right. European political science, 18(3), 400-420.

Taras, R. (2012). The end to immigration by a thousand cuts?: on Europe's bureaucratic gatekeepers. Malmö University, Malmö Institute for Studies of Migration, Diversity and Welfare (MIM).

Thym, D., \& Hailbronner, K. (2016). Legal Framework for EU Asylum Policy. published in: Kay Hailbronner and Daniel Thym (eds.): EU Immigration and Asylum Law. Commentary, 2nd edition $(\mathrm{CH}$ Beck/Hart/Nomos, 2016), 1023-1053.

UNHCR (2015). Press Coverage of the Refugee and Migrant Crisis in the EU: A Content Analysis of Five European Countries. Available online at: https://www.unhcr.org/protection/operations/56bb5a876/ press-coverage-refugee-migrant-crisis-eu-content-analysis-five-european.html

Van der Brug, W., \& Fennema, M. (2003). Protest or mainstream? How the European anti-immigrant parties have developed into two separate groups by 1999. European Journal of Political Research, 42(1), 55-76.

Van der Brug, W., Fennema, M., \& Tillie, J. (2000). Anti-immigrant parties in Europe: Ideological or protest vote? European Journal of Political Research, 37(1), 77-102.

Van Spanje, J. (2010). Contagious parties: Anti-immigration parties and their impact on other parties' immigration stances in contemporary Western Europe. Party Politics, 16(5), 563-586.

Wong, C. J. (2007). "Little" and "big" pictures in our heads: Race, local context, and innumeracy about racial groups in the United States. Public Opinion Quarterly, 71(3), 392-412.

Y1ldı, A. G. (2016). The European Union's Immigration Policy. Managing Migration in Turkey and Morocco. Palgrave Macmillan UK.

Zalan, E. (2016) 'Hungary Refuses to Take Back Migrants from Austria'. euobserver.com,

Zhou, P., Ang, B. W., \& Poh, K. L. (2007). A mathematical programming approach to constructing composite indicators. Ecological economics, 62(2), 291-297.

Zolberg, A. (2006). Las migraciones internacionales desde una perspectiva política. Zona abierta, 116, 25-58.

Publisher's Note Springer Nature remains neutral with regard to jurisdictional claims in published maps and institutional affiliations. 